石油技得会誌 50 卷 3 号 (称 60 年 5 月)

JOURNAL OF THE JAPANESE ASSOCIATION FOR PETROLEUM TECHNOIOGY

VOL. 50 , NO. 3 (May, 1985)

\title{
奥羽脊梁最下部グリンタフ，大荒沢層の形成期*1
}

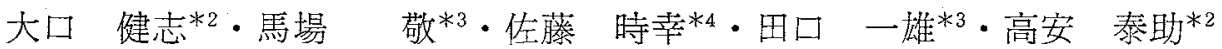 \\ (昭和60年 1 月 28 日受付，受理 3 月 22 日)
}

\section{On the Age of the Oarasawa Formation, The Lowest Green Tuff in the Ou Backbone Mountain Range, Northeast Japan}

By

\author{
Takeshi OHguchi, Kei Baba, Tokiyuki SATO, \\ Kazuo TAgUCHI and Taisuke TAKAYASU
}

\begin{abstract}
Remarkable fossil plants and marine animals were found from the Oarasawa Formation distributing along the upstream of the Isawa River, southwestern part of Iwate Prefecture, near AkitaIwate border.

The Oarasawa Formation, the lowest Neogene sequence in the Ou Backbone Mountain range area, has been correlated to the Nishioga Group or the Monzen Group of Oga Peninsula on the basis of characteristic lithofacies called "Oarasawa-Semi facies" without enough fossil evidence. The Oarasawa Formation outcropping along the Isawa River is composed mainly of subaqueous basaltic to andestic volcanic rocks and intercalates conglomerate, sandstone and siltstone layers, in which the fossil were newly found.

The plant fossils include some characteristic species of the Daijima-type fossil flora such as Cyclobalanopsis nathorstii, Quercus miovariabilis, Liquidamber miosinica and Smilax trinervis being determined by Professor emeritus K. Huzioka. The fossil marine animals are not abundant and poorly preserved, but the fossils contain a few common species of the Kadonosawa fauna that is nearly equivalent of the fauna in the Nishikurosawa stage.

The fossil evidences show: that the Oarasawa Formation is now placed in the Daijima-Nishikurosawa age. Therefore, by bicstratigraphical and lithological facts, the Oarasawa Formation can be correlated consistently with the formations which were established or redefined recently, such as the Okachigawa Formation of Dewa mountoins, southern Akita Prefecture and the Sunakobuchi Formation distributting along the eastern margin of the Akita Oil Field.

The litho- and biostratigraphical informations obtained recently from the lower Green Tuff, indicate that the Green Tuff volcanism took place in the Daijima-Nishikurosawa age in many places of the inland region of the northeast Japan.
\end{abstract}

\section{1. まえがき}

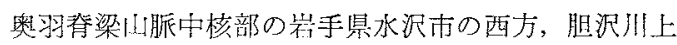
流飞分布与る大萦沢層（北村，1959，1965）加与，動植 物化石が産出した。産出化石の内容は，大范沢層の形成 期が赤島期一門前期ではなく，台島一西黒沢期（藤岡展 价ら，1981)であることを示している(㫮場ら，1984a， b)。

*1地質学会第91年会 (東京), 石油技術協会第49回総会（秋田）で講演。 *2秋田大学鉱山学部

*3東北大学理学部

*4帝国石油稀技術研究所
大荒沢層準から今采で知られている化石は，秋田真 の桑の木沢産海楼二收具破片のみであった(北村，1965； 武藤，1965）。大萝沢曆に限らず，大荒沢一門前層相当層 といわれる最下部グリンタフの多くが古生物資料を欠く 状態は，近年まで綂いた一般的なことであった。そのた

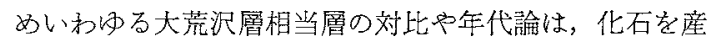
出する上位層との層位関係, 䀾相の共通性, さらには変 筫状態さ光加昧して行わざるを得なか力た。鑑定に耐党 る化石が稀に発見されたとしても，その地域の層序を改 訂するにとどまり，大荒沢層，あるいは最下部グリンタ フの形成期まで踏みこんた考察は行われなかった（例え 
図 1 位置図

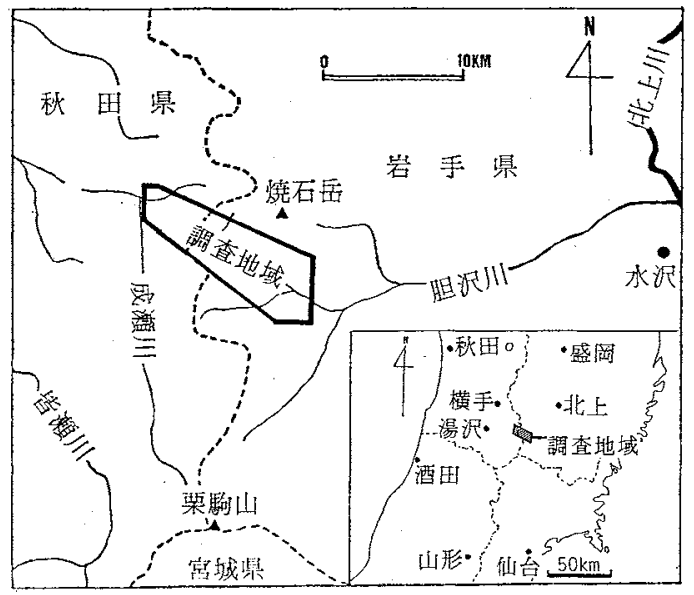

ば，大口，1974)。李た，要場合に惊産出する化石内 容を全く無視した詳諭すらなされた。

秋田油田東縁の太平山地域の萩形層（沓沢，1966, 1977 ；藤岡一男占，1977）加，馬場ら（1979）は台島 型植物化石, Operculina sp. indet. などの海捿動物化 石を発見した。馬場ら（1980）はそのこと火基づいて， 大荒沢一瀬見相（田口，1973a，b）と乎ばれるものの大部 分が，台島一西黑沢層相当層である可能性を示唆した。

北村 (1959，1974）によって体系ゔけられた奥羽春梁 新第三紀地史の発端を示李大荒沢居の形成期，ひいては 春梁グリンタフ火山活動の開始期は，本報によって初め て，克生物学的根拠を持つこととなった。

大荒沢層の形成期関豆る新しい知見は，下部グリン タフの位置づけ，並びに，炭化水素鉙床の滐部探查に， 影響を与えるすのと思われる。本稿で隹，化石産出地点 付近の大荒沢層の岩相と層序を記載し，座出化石がすつ 地質学的意義を出羽丘陵のグリンタフ地質と関連させて 考察する。

図 2 地質図（岩手県胆沢川上流～秋田県成瀬川支流，柳沢間），北村（1965），臼田5（1977）加5編集。

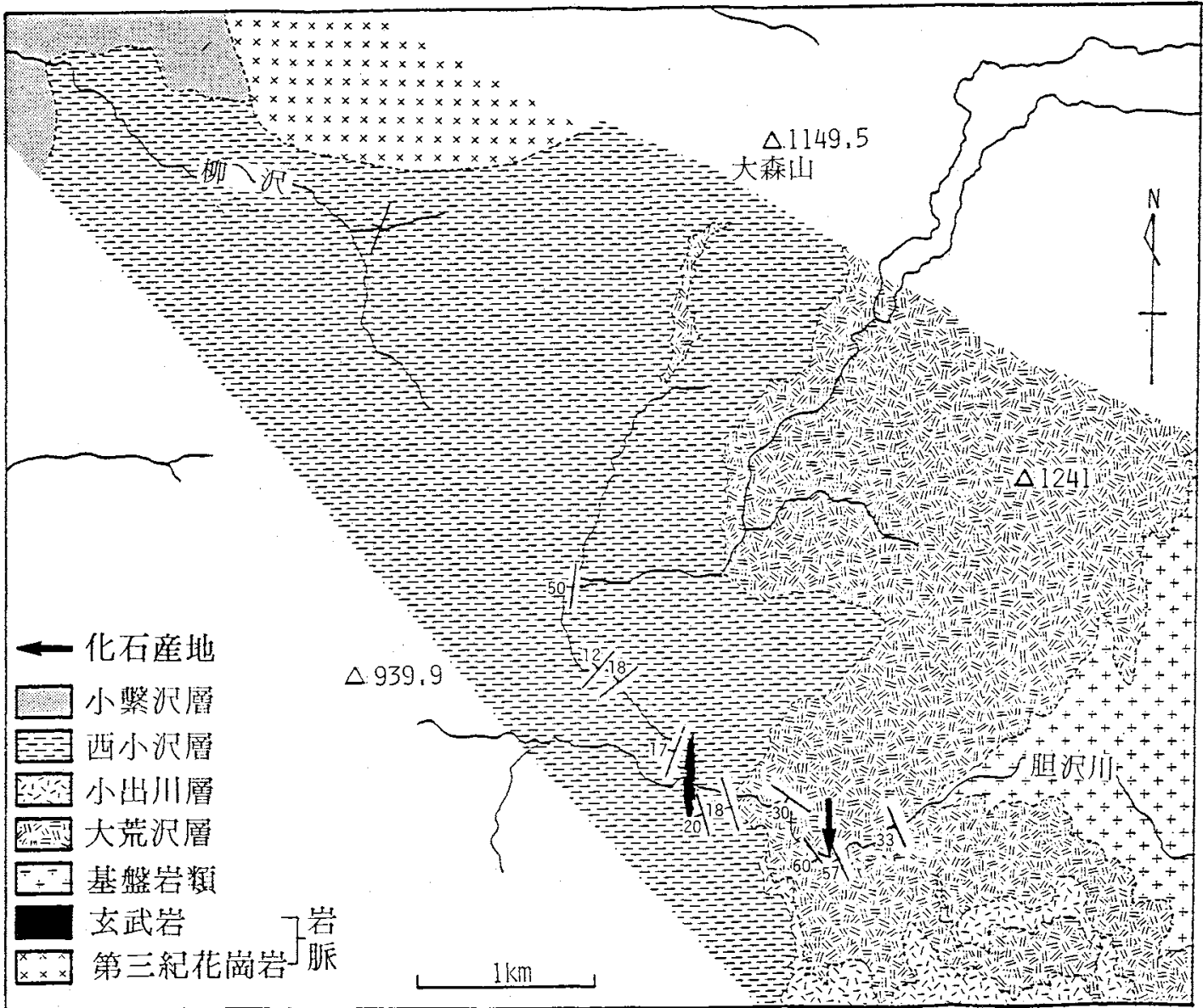


表 1 地質総括：北村 (1965)，日田ら（1977）による。

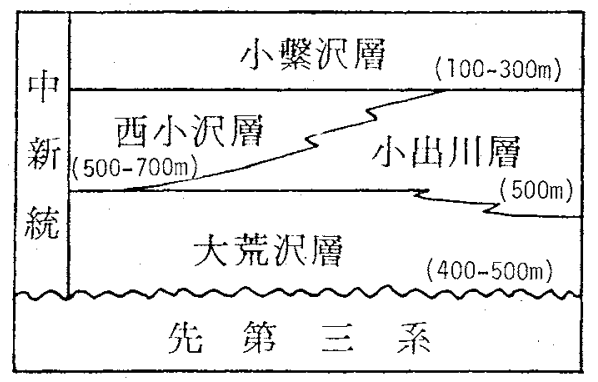

な叔，産出した化石の詳細については，改めて報告の 茅定である。

\section{2. 地質と産出化石}

岩手買胆沢川上流域の新第三系は早川ら (1954) と北 村（1959，1965）によって報告されている。表1に北村 （1965）と曰田ら（1977）加ら編集した，胆沢川上流から 目境を越克て秋田罢成瀨川支流柳沢に至る地域(図 1)0 層序を，図 2 亿著者らの資料を加光な地質図を示す。

古生界堆積岩類と, それに貫入した閃緑岩類, 超塩基 性岩類から構成される基盤岩類（北村・蟹沢，1971）に 重なる中下部新第三系は，圈示の如く，下位より大荒沢 層, 小出川層, 西小沢層, 小繋沢層に区分されている。 小山川層の下部は大荒沢層の上部と指交し，西小沢層は 小出首と同期の地層とされている（北村，1965）。

図 3 胆沢川上流, 桑原岳背斜西翼の大荒沢層柱状図

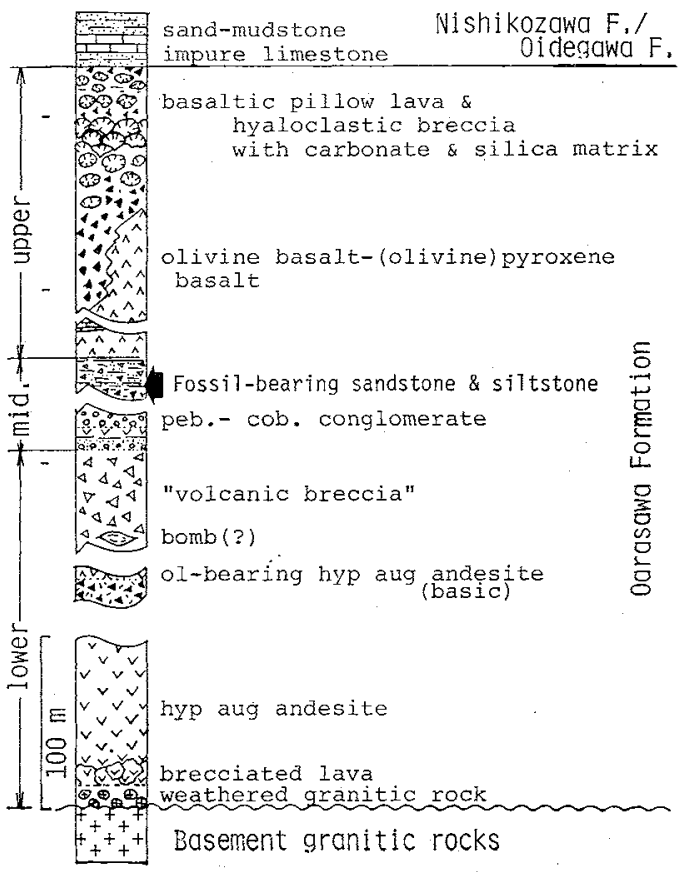

大荒沢層をはじ，これらの地層は，男鹿半島の西男 鹿層群から女川層までの地層に対比されている(北村， 1959)。

\section{1 胆沢川上流に分布する大荒沢層の記載}

胆沢川上流の大范沢層は，変朽安山岩類が主構成員と されて㧍り，早川ら (1954)により胆沢川層と呼ばれて いた。北村 (1959，1965) は，胆沢川層や秋田県側に分 布与る桑の木沢層（武藤，1965）の㞸相と層位が標式地 (横黑線二北上線沿線) の大荒沢層と等しいことから， それら雨層を大荒沢層に一括し，現在に至っている。

桑原岳背斜（北村，1974）西望，胆沢川にそう柱状図 を図 3 亿示す。大荒沢層は風化花崖岩層を介して先第三 系を覆い，不純石灰岩，砂辰一泥岩からなる小出川層和 よび西小沢層によって覆われる。この地域の大荒沢層は 化石を含を碩岩〜シルト岩層を中部として，安山岩類か らなる下部と，玄武岩類を主とする上部とに 3 区分され る。全層厚は $450 \mathrm{~m}$ 程度である。

〈下部〉しそ輝石・普通輝石安山岩，和上び，含か 几らえ石，乙先輝石，普通輝石基性安山岩溶岩，火山角 礫岩、ハイアロクラスティックブレッチャ(hyaloclastic breccia)などからなる。安山装溶岩は，班状，部分的に集 斑状で，石基は填間状組織を呈し，新鮮な暗褐色火山ガ ラスが石基见残存することが多い。火山角磞岩は $30 \mathrm{~cm}$ 大以上に和よぶ，様ふな大ささの安山岩片や火山弾様炭 片を含み，岩瑰の一部は赤〜赤褐色を呈し，少量の炭酸 堨鉱物によって膠結されている。

く中部〉礫岩，砂岩，シルト岩などから棈成され， 約 $50 \mathrm{~m}$ の層厚を持つ。7 $\mathrm{m}$ 伍どの厚さの安山岩溶岩を下 部に塽在する。

動植物化石はこの中部層の上部に含李れている。すな

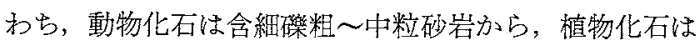
その值上の炭質部に富むシルト岩や中～粗粒砂岩から産 出する。含化石層の層厚は約 $70 \mathrm{~cm}$ である。

〈上部〉 無斑䐯〜班状の，かんらん石輝石玄武岩一 輝石玄武岩質柱状溶岩，ハイアロクラスティックプレ ッチャ (hyaloclastic breccia) (河内ら，1976)，ペペライ ト (peperite)などの水冷溶岩から棈成され，そのらち下 部ではやや塊状である。枕状溶岩は，ピロー(pillow)の 間に基質をとるど欠いて密に集合したクローズパッ クドピロー (close-packed pillow)，粗く成層したハイ アロクラスタイト (hyaloclastite) 中に個々のピローが散 在するアイソレイテッド ピロー（isolated pillow)など

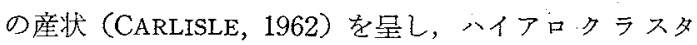
イトを主体とする部分とピローの濃集する部分とが，1 〜 $2 \mathrm{~m}$ 間隔で互層することもある。

枕状溶岩の一部を含め, ペペライト，ハイアロタラス 
ティックブレッチャなどの角礫化岩相はその角砅の間 を，泥質物，炭酸塩鉱物，石英なぼが允筫する。一部の 岩片は水冷溶岩片に特徴的な石基組織の蒂状变化を示 के。

上部層は急冷ガラス部分の変質，あるいは細脈状に双 觉る充樭物によって，見掛け上，下部層よりも強く変質 している卵象を受ける。しかし，ピローやブレッチャ内 部の普通輝石や斜長石は新鮮なことが多い。

\section{2 化 石}

動植物化石は前節で述べたよらに，大荒沢層の中部か ら産出する。植物化石は動物化石産出層準の上位加見 い出さ机る。現在わかっている産出地点之層準怔 2 と 3に示す1個所のみである。

化死はいずれる卵象化石ですり，保存状態は良くな い。しかし，野外で取り出した化石，特に植物化石の多 くは，充分鑑定に㳡えるものであった（表2）。

表 2 大荒沢層産動稙物化石（鑑定：植物化石：藤烊一 男, 動物化石: 高安泰助)

\section{Plant Fossils}

Pterocarya sp.

Cyclobalanopsis nathorstii (KRYSHTOFOVICH) HUZIO$\mathrm{KA}$ et TAKAHASHI

Cyclobalanopsis sp.

Pasania sp.

Quercus miovariabilis $\mathrm{HU}$ et CHANEY

Zelkova ungeri (ETT.) KoVATS

Ficus sp.

Magnolia sp.

Cinnamomum sp.

Liquidamber miosinica $\mathrm{HU}$ et CHANEY

Liquidamber sp.

Paliurus sp. (leaves and seeds)

Smilax trinervis MORITA

Marine Fauna

Soletellina sp.

Panomya cf. simotomensis OTUKA

Mya sp.

Mya? sp.

Hiatula of. minoensis (YOKOYAMA)

Turritella (Hataiella) cf. s-hataiii NOMURA

Euspira? sp.

fish bone?

〈植物化石〉11属13種が同定された。鑑定者である 藤岡一男名誉教授によれば，この化石植物群の特街とし て，針葉樹を伴わないこと，沿海岸低地一後背山地斜面 に生育した暖带的落葉広葉〜照葉林（藤网・植村, 1979） 要素が強いことなどがあげられる。特に大荒沢層から産 出した Cyclobalanopsis nathorstii (KRYSHTOFOVICH) HUZIOKA et TAKAHASHI, Quercus miovariabilis HU et CHANEY, Liquidamber miosinica $\mathrm{HU}$ et CHANEY, Smilax trinervis MORITA などは，いずれも台島型植 物群に特徵的な種である。

以上のことから，大荒沢層産植物化石は秋田紧阿仁合 炭田の打当植物群（HUZIOKA，1963），出将丘陵の烟 村植物群 (HUZIOKA，1964), 庄内平野の上郷植物群 (TANAI，1961；藤岡・古賀，1981)などの台島梨植物 群に対比できる。

〈動物化石〉 植物化石と比べ，種数が少なく，かつ 保存も悪い。Panomya cf. simotomensis OTUKA, Hiatula cf. minoensis (YOKOYAMA), Turrïtella cf. s-hataii NOMURA の産出は，この産出層準が門の沢動物群 や台島一西黑沢期を示す動物群に效比できる可能性を示 巍す。

Panomya，Mya の産出は，胆沢川上流に分有寸る大 荒沢層の堆積環境が上位の小出川層の去秃(北村，1965) よりる, 内湾性であったことを示しててる。

前述の動植物化石，特に檩物化石盗料に基すくと，大 荒沢層は台島一西墨沢期淮積物（藤岡ら，1981）として 位置づ汁ら机る。

\section{3. 対比と考察}

替梁地域に分布する大荒沢勫などの最下部グリンタフ は，大荒沢一瀬見相（田口，1973a，b）と呼ばれ，いわ ゆる “プロピライト”で特徴づけられている。従来, こ のよらな斉一的特徴を示す岩相によって，大荒沢層は男 鹿半島の門前層群あるい绀西男鹿群, 秋田油田の大又層 拉よび，その上位の藏形層心対比されていた（表 3）。

1960年代前半までに総括されていた東北目本内带グリ ンタフの研究は田口（1973a，b）飞始委る一連の出羽丘 陵下部グリンタフ層序改訂の進行, 無化石とされていた 下部グリンタフからの化石の発見，坑井資料の增加な ぞ，新しい資料の整㣁により，一つの転換期を迎光た (藤岡5,1981；OHGUCHI，1983）。ここでは，台島一西 黒沢期堆穦物としての大荒沢層と, 出羽丘陵などで得た 知見を総合し，い和ゆる大莣沢層準の対比を試みる(表 4)。

秋田県南部〜新庄盆地北部の及位層 (表3-3)), 横暒趾 層などは, 湯の沢川層, 雄勝川層, 飯沢層, 皿川層, 大 仙山層火細分された（大沢ら，1979a，b)。及位地域の赤 倉凝灰岩（大沢 - 角，1961）品, 馬場ら（1983）は植 物化石，昆虫化石（トビケラ，藤山（1983）同定）を採

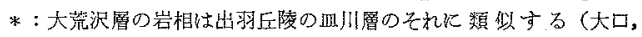

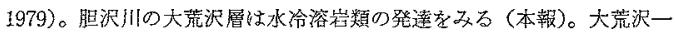
瀨見相とよばれる特徽岩相は水中に和汗る火山活動，あるいは入水溶宸 によってもたらされたものかもしれない。 
表 3 従来公表されてきた下部グリンタフの対比

1)藤岡一男 (1959)，2)井上, 1960，3)沓沢 (1963)，大沢 - 角 (1961)，4) 北村 (1959,1974)，5)-a)大口・ 伊里 (1977)，5)-b)早川 (1954)，村井 (1962)，6)上因（1965），早川5 (1954)下上る。

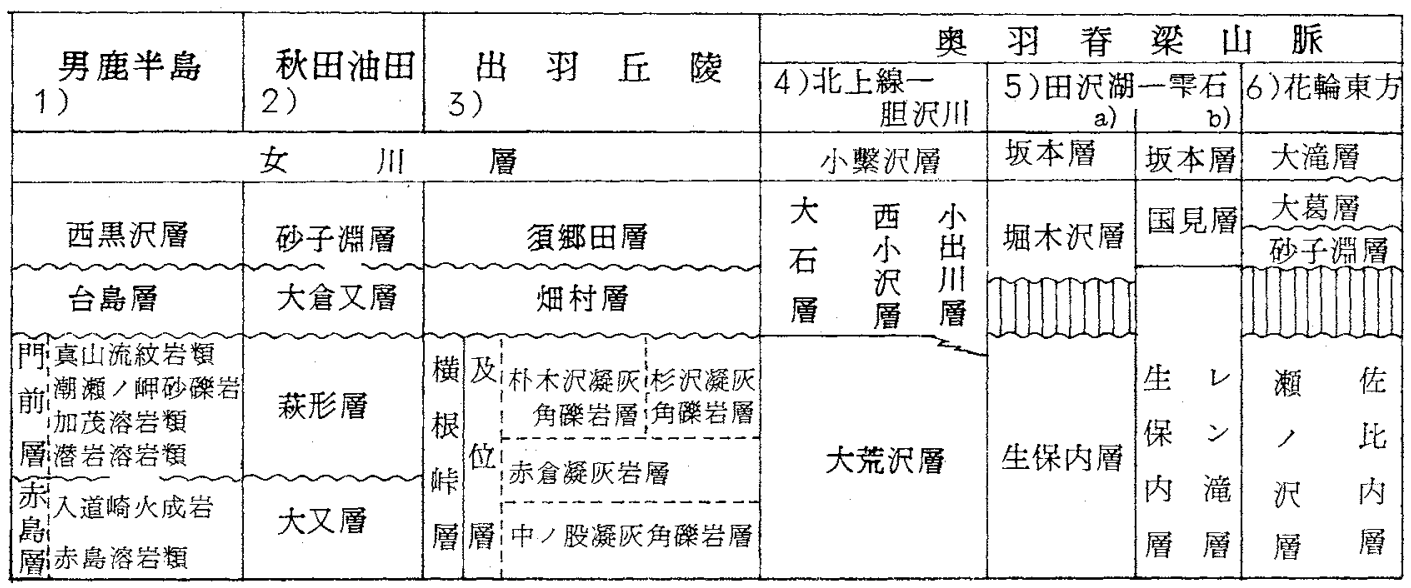

表 4 新しく改定した対此表：台島一西黒沢期堆積物としての大荒沢層を改定が進んだ地域と対忍させた。

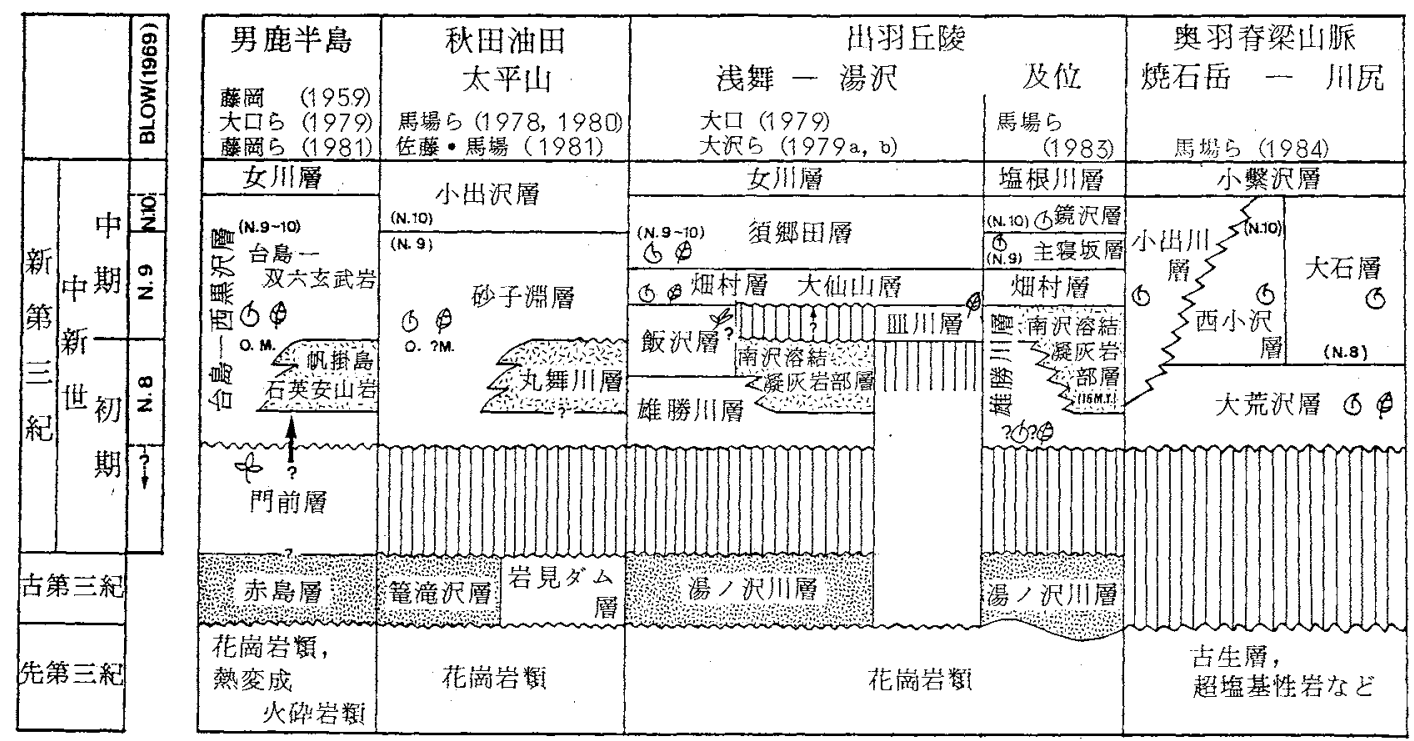

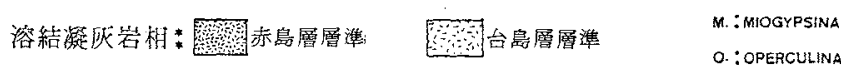

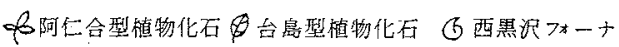

集した。植物化石の保存が恵く，種の同定は不可能であ った。鑑定者（藤岡一男教授）によれ虫，属の構成内容 から台島型植物化石である可能性が高い，とのことであ b。

湯沢地域雄勝川!層の南沢溶結凝灭岩部層は，及位層標 式地へよく追跡され，化石を産出する赤会凝兏岩と指交 する。このことから，及位層索雄勝川層の南方延長とし て，把光ることができる。化石産出愿準の㞸相は，北方 の四川層，飯沢層などとも類似する。
かつて，西男鹿層群付対比されていた新庄盈地の檜原 沢層は, Cinnamomum sp. 産し, さらに西黑沢階を 示す具類化石を含孚（田口，1974）。以上のことから， 田口 (1973a. b) は檜原沢層走赤倉凝灰岩とともに, 台 島痛に対比した。

沓沢(1963)が及位層の赤倉凝灰岩や門前層に対比した 横根趾層*(表3-3)）值，物化石を産出する。HUZIOKA

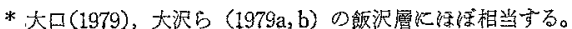


（1964）はこれを横根小植物群と呼んで, 阿仁合植物群 と同時期のものとした。その根执は，当時行われていた 産出層準の対比に基づいている。

秋田県東南端, 雄勝町秋の宫侄分布する及位層から, 大口 (1974) \& Amphistegina radiata の他に貝類化石 を発見し，その地域の及位層の大部分を台島艄～西黒沢 吿相当層とした。

以上のよ5として，秋田柰南部の出羽山地のい和る 大荒沢一門前層準の地層の大半は，大荒沢層々同様，台 島一西黒沢階の地層とみなさざるを得ない状況となって いる。

秋田油田の東縁にあたる太平山塊周辺を標式地として 設定された，表 3 に示す下部グリンタフ層序(井上， 1960) は沓沢 $(1966,1977)$ ，藤岡ら (1977) などによって 改变され，使用されてきた。馬場ら $(1979 ， 1980)$ は太平 山塊南西部に広がる井上の大倉又層, 沓沢, 藤岡の萩形

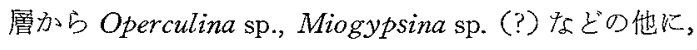
数種の西黑沢期を示す動物群に属する化石の産出を報告 した。貝類化石産出層準の上位からは Cinnamomum miocenum を産出する。佐藤・馬場 (1981) は同じ地域 の萩形層 (門前階) から “砂子㴊層”(西黑沢階) 交での 微化石を検討した。气の結果，太平山塊南西部代分布す る萩形層は，并上 (1960) の大又層相当層（篭滰沢層， 岩見ダム層) と, 西黑沢海進に伴ら一連の堆積物（再定 義した秒子㴊層）からなることが判明した。すないら， そこで情門前階の地層が認定できないことを示してい る。再定義された砂子㨽層は，岩相からる，生層序の上 からす，大荒沢層とよく対比できる。

零石兺地西縁の大荒沢層相当層，レン潼層（表3-5)） (村井，1962）はデスモスチルスを産出する（小野寺ら， 1967)。大口・急里(1977) はレン滝層の上部を，ほほ 西黑沢曆に相当する堀木沢層下部位置つけた。“大荒 沢一瀬見相”に相当する田沢湖線沿線の生保内層の対比 は, 大荒沢層の対比の変更に伴い，改める必要がある。

門前期の海成層とされていた秋田目北部の花輪盆地東 部炕分布する瀨の層沢(表3-6)）は，井上ら (1973）に よって再定義された。彼らによれば，阿仁合型植物化石 で特徽づけられる下部は安久谷川層として分離され，瀬 の沢層は台島一西黑沢期堆積物に限定される。四田ら （1982）は佐此内層（早川ら，1954）も限定された瀬の

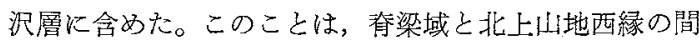
に分布する，傾城峠安山岩などの大荒沢層相当層の対比 が将来変更されるであるらことを示唆している。

\section{4. むすび}

大莣沢層の形成期が台島一西黑沢期であることを，䂟
手県胆沢川上流の大荒沢層から今までに見い出された， 台島型植物化石と海棲動物化石に基ついて述べた。さら に胆沢川の大荒沢層の岩相を蚂載し，その中上部が枕状 溶岩を伴う水冷溶岩からなることを迹べた。無化石める いは化石に㞯しいといわ机ていた地層から大型化石が発 見されたことは，㸹来これらの地層の微化石資料が充実 されるで出ららことを亦している。

出羽丘陵，秋田油田巢縁和よび瓷梁地域比叔ける化石 産出層集の発見亡層序の改定は，これらの地琙で門前期 とされていた地層の多くが，台島一西黑沢期のものであ ることを明らかにしつつるる。そして，門前期に形成さ れた地層は, 標式地の門前曆, 太平山北方の阿仁合炭田 の堆積物と同価の萩形層（井上，1960）など，一部を残 すのみとなった。

男鹿半島の赤鳥層に対比されている太平山塊の大又層 （井上，1960）は，出羽丘陵の湯の沢川層などととも に，日本海沿岸山地を特幑うける古第三紀の火山活動の 産物亡考员られる（大口ら，1979；大口，1983）。

内陸部で下部グリンタフの層序改訂が進展したため, 今まで岩相によって対比されていた男鹿半島下部層と内 陸のそれとを対応させることは困難である。男鹿半島域 で火山活動の場が水域に転换した時期は，火山岩類の産 状から，潜岩溶岩数と汪ぼ同時に活動した加茂溶岩類の 噴出期である。前述した内陸部との対此の困難さを解消 するためには，この水域の性格を解明し，半島下部グリ ンタフ地質の検竐を続け，古生物資料を増加させること が必要であるら。このような検討はまた，広琙的斉一火 山岩相（たと光ば，大荒沢一瀬見相），あるいは火山一火

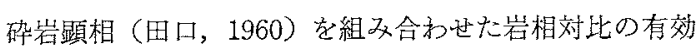
範专の確定に死役立つと思和る。

\section{謝 辞}

䅦物化石は视田大学・藤阔一男名誉教授に鑑定してい ただいた。先生にはさらに，粗稿龙校閲していたださ， 壆重な御意胃索賜った。植物化石標本は国立科学博物館 の權村和彦氏飞も御覽いただき，有益な御意見を何うこ とができた。热た，化石標本は，植村氏に預託し，引き 続き詳細な研究を和願いしている。以上の両氏に厚く感 謝の意求しあす。

\section{引用 文 献}

馬場 敬・伊藤雅之・大口健志・岡本金一・後藤 求・传

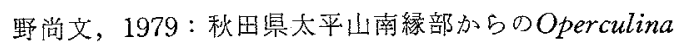
の発見和よびその意義（要旨），地質学会東北支部会 報，（9），16-17.

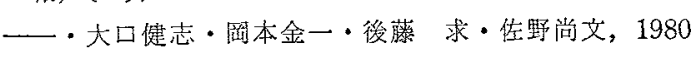


: 秋田県大平山南粶部の層序一特K Operculina 発見 の意義について一(演旨). 石技誌, 45 (4), 231 . 一一, 1981 : 鉱物に括けるフィッション・トラックのエ ッチングの問题点及びその解法. 堆積学研究会報, (16), 17-28.

——越川憲一・田ロ一雄・仿藤時幸，1983：新庄盈地 東縁下部グリン・タフ層序の再検詩扎よびその意義に ついて(演旨). 石技誌, $48(4), 312$.

一一佐藤時幸・大口健志, $1984 \mathrm{a}$ ：犬荒沢屬加発罗 された動植物化石とその意義（演旨）．地質学会第 91 年会講演要旨集, 119.

一一大口健志・位藤時幸，1984b：出羽丘陵加ら奥羽

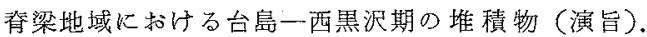
石技誌, $49(4), 51$.

CARLISLE, D., 1962: Pillow breccias and their aquagene tuffs, Quadra Island, British Columbia. Jour. Geol., 70, 48-71.

藤岡展价 · 大口健志 - 米谷盛寿郎 - 曰田雅郎・馬場 敬, 1981：東北重日本地域に屾る台島一西黒沢期の堆積 物について，石技誌，46(3)，159-174.

FUJIYAMA, I., 1983: Neogene Termites from northern district of Japan, with references to the occurrence of fossil insects in the district. Mem. Natn. Sci. Mus., Tokyo, (16), 83-99.

早川典久・舟山裕士・衼藤邦三・北村 信，1954：岩手 県北上山地西縁より瓷梁山地火亘る地域の新第三系の 地質。東北鉱山，(10)，1-97.

藤岡一男，1959：5万分の1地質図幅「户賀」・船川11， 及び闰説明書，地謂，1-61.

HUZIOKA, K., 1963: The Utto flora of northern Honshu. Tertiary Floras of Japan, Miocene Floras, Collab. Assoc. Commen., 80th Ann. Geol. Surv. Japan, 153-258.

-1., 1964: The Aniai Flora of Akita Prefecture and the Aniai-type floras in Honshu, Japan. Jour. Mining Coll. Akita Univ., series A, 4 (4), 1-105.

藤烊一男 - 大沢 澧 - 高安泰助 - 池辺 欀, 1977 : 秋田 地域の地質。地域地質研究報告 ( 5 万分の 1 四輻)，地 調, 1-75.

一一植利和彦，1979：中新世中期，台島階における Comptonia-Liquidamber forest. 秋田大学地研報， (45), $37-50$.

一一古賀 孝, 1981 : 東北地方西南部の中新世中期台 岛型植物群. 地学雑, 90 (4)，235-246.

池辺穣, 1961：秋田油田地域に括汁る含油第三系の構 造発達之在油の集積见ついて。秋田大学地研報，(26)
$1-59$.

井上 武，1960：秋田油田地域伝打讨る含油第三系和上 びその基盤グリンタフの火成層序学的研登。秋田大学 地研報，(23），1-79.

一一垂富一雄・上田良一・四田雅郎，1973：秋田県総 合地質図幅「花輪」，及び同説明畫。秋田県，1-54. 河内洋作・LANDIS, C.A.・渡辺量夫，1976：ハイフロク ラスタイト。地質雑，82（6)，355-366.

北㭙 信，1959：東北地力に和汀る第三紀造山運動につ いて一奧羽春梁山眽を中心として一。東北大学地質古 生物邦文報，(49)，1-98.

1965：5万分の1地質図幅「焼石岳」及び同説明 書. 地調, 1-40.

- 蟹沢聰央，1971：奥羽替梁山脈㜔石岳南麓の先第

三系基盤岩類について，東北大学地質古生物邦文報，

(71), 61-66.

一一, 1974 : 東北日本の新生代変動史. 海洋科学, 6

( 9 ) $622-629$

沓沢 新, 1963：中新世に扣ける“田代不整合”の意義 （その1）一出羽丘陵・横手盆地西縁部の地質. 地質 雑, 9 (816), 421-436.

一・太平山団研グループ，1966：太平山南縁部の新第 三系の層序と構造一とくに，グリーンタフ活動様式と 堆積作用，剪裂蔩形成運動の相互関係一。地団研專 報，（12），73-94。

一，1977：東北グリーンタフ棈造運動人の一試論,

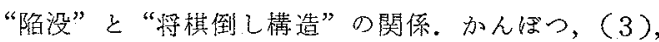
43-49.

村井貝允，1962：岩手県零石盆地の地買(その3), 䨛 石盆地西縁部の地質。岩手大学工学部研報， 15 (1), $51-63$.

武藤 章, 1965 : 秋田県菓南部地域の新第三系の層序. 地質雑，71 (839)，389-400.

大口健志, 1974：秋田県南部・雄勝町秋の宮の地蜇一 Amphistegina おょび具化石層準の発見一。秋田大学 地研報，(42)，1-11.

一一伊里道彦，1977：秋回県田沢湖町生保内一岩手県 需石町橋場間の地質。秋田大学地研報，(44)，67-81.

一一矢内桂三・植田良夫・玉生志郎，1979：男鹿半島 第三系・又道崎火成岩心岩相と放射年代．岩鉱，74 (6), $207-216$.

一, 1979 : 秋出県南部の第三系下部層。秋田大学地研 報，(45)，65-72.

-一，1983：秋田県西部の下部グリソタフ層序．国立科 博專報，（16），13-23.

OHGUCHr, T., 1983: Stratigraphical and petrographical 
study of the late Cretaceous to early Miocene volcanic rocks in northeast inner Japan. Jour. Mining Coll., Akita Univ., series A, 6 ( 3 ), 189-258.

小野寺信吾 - 大䉆俊介・佐藤二郎・高橋德夫 ·山田弥太 郎, 1967 : 岩手県零石町南部のグリーンタフ層からデ スモスチルスを発見. 地質雑, 73 (6)，309-311.

大沢 穠・角清 愛，1961：5万分 1 口地質図幅「羽前 金山」及ぴ同説明書. 地調，1-66.

-大口健志・高安泰助, $1979 \mathrm{a}$ ：湯沢地域の地質. 地域地質研究報告（5万分の1図幅），地調，1-64.

————, $1979 \mathrm{~b}$ : 浅舞地域の地質. 地域地質 研究報告 ( 5 万分の 1 図幅). 地調，1-53.

佐藤時幸・馬場 敬, 1981：秋田狋太平山南縁部グリン タフ層準の微化石について(演旨). 石技誌，46(4)， 273 .

田口一雄, 1960：出羽丘陵新第三系下部層について（出 羽地向斜の研究一正). 地質雑, 66 (773)，102-112.

一1961：山形県最上郡小国川南方山地の新第三系（出
羽地向斜の研究一 $\mathbb{V}$ ). 地質雑, 67 (786)，157-170. 一，1973a：裹日本新第三系下部層にまつわる問題一 特炕基盤構造地質々積成区の形成に言及して一（出羽 地向斜の研究一V). 山形目の地質と資源， 17-28.

一，1973 b : 東北新第三系下部層の火山層序と放射年 代. 地質学論集，（8），183-193.

一，1974：5万分の1地質図幅「新庄】及び间説明書. 山形県, 1-22.

TANAI, T., 1961: Neogene floral change in Japan. Jour. Fac. Sci., series 4, 11 (2) 119-398.

上田良一，1965：秋田県北部の第三系の層位と造構造運 動について. 秋由大学地研報, (32)，1-71.

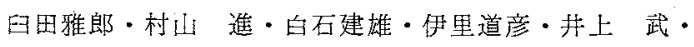
乗富一雄, 1977：5万分の1総合地質図幅「横手」及 び同説明書. 秋田県, 1-97.

一岡本金一・高安泰助・成田典彦・栗山知士・藤本 幸雄，1982：5万分の1地質図「田山」. 秋田目。 